\title{
LITERARY SOURCES FOR THE HISTORY OF PALESTINE AND SYRIA: THE MARI ARCHIVES
}

DENNIS PARDEE

University of Chicago

This is the first in a series of bibliographical articles on the extrabiblical written sources available to the historian who wishes to deal with the OT period and with the general area of Palestine-Syria. Its purpose is to acquaint the readers of this journal with the main bodies of texts to which reference is often made in books and articles treating that period. Inasmuch as readers of this journal include many whose specialization is other than OT, a general introduction will be given as well as the kind of bibliographical introduction which will permit those who are so inclined to consult the original and secondary literature on their own.

\section{The Site}

Mari, the ancient city which once occupied the mound which now goes by the name Tell Harîri, is located on the right bank of the Euphrates in Syria, about ten miles north of the Iraqi frontier. Its importance lies not so much in its location as in its inhabitants at the beginning of the second millennium B.C.: Their native language belonged to the family from which the Hebrew of the OT sprang (termed the "Northwest Semitic" group of languages by linguists', and thus when we trace the language and history of the inhabitants of Mari, we are in a sense mapping the family tree of the biblical Hebrews.

\section{Archaeology}

The first campaign at Tell Harîri was carried out by André Parrot and a French expedition during the winter months of 1933-34, and has been reported by Parrot, "Les fouilles de Mari. Première campagne (Hiver 1933-34). Rapport préliminaire," Syria 16 (1935): 1-28, 117-140. Since that first session, preliminary reports of twenty more campaigns have been published in Syria, 
the twenty-first in 52 (1975): 1-17. Also, the final comprehensive reports have begun to appear, as follows (all by Parrot in Mission archéologique de Mari [abbreviated hereafter as MAM], published by Geuthner in Paris ): Le temple d'Ishtar, MAM 1, 1956; Le palais: Architecture, MAM 2/1, 1958; Le palais: Peintures murales, MAM 2/2, 1958; Le palais: Documents et monuments, MAM 2/3, 1959; Les temples d'Ishtarat et de Ninni-Zaza, MAM 3, 1967; Le "trésor" d'Ur, MAM 4, 1968. Parrot himself has recently summed up the finds, both archaeological and epigraphic, with good bibliography: Mari, capitale fabuleuse (Paris: Payot, 1974).

The most spectacular finds fall into two categories: texts and architecture. To date more than 20,000 tablets have been found, as well as inscriptions on stone, cylinder seals, jewelry, etc., in far smaller number. The contents of the tablets are the main topic of this report.

As to the architectural discoveries, the most astonishing was that of a series of superimposed palaces stretching over a period of at least a thousand years from early in the third millennium в.c. (Early Dynastic II-III or pre-Sargonic in archaeological/ historical terms) to early in the second millennium B.C. (the Old Babylonian period). The earliest palace (Pre-Sargonic II) is, of course, the deepest in the mound, and is now the least exposed. Nonetheless, several large rooms of the sacred portion of this palace, complete with altars and libation pits, have been completely excavated, as have also several of the surrounding rooms and corridors.

The plan of the later palace (Pre-Sargonic I) is the same as the earlier, with walls, altars, etc., all superimposed over a period of several hundred years. Parrot has been speculating in the last few preliminary reports as to whether or not a "Pre-Sargonic III" palace will be found. This is a prime example of the long-term "bated breath" required of archaeologists. Frequently one must wait a decade or more for the answer to a haunting question. 
In addition to the pre-Sargonic palaces, several temples of these periods have been found (those of Ishtar, Ishtarat, and Ninni-Zaza have already seen final publication, in reports noted above). The most striking epigraphic finds of these early periods are short references to Ansud (also written Ansub and Hanusu), king of Mari, and to Mesannipadda, king of Ur, discussed by Parrot in Syria 42 (1965): 23, 220-225. These kings are presented in the Sumerian king list as founders of dynasties in Mari and Ur, but before Parrot's finds only Mesannipadda was known from contemporary sources (the Sumerian king list itself dates from a later period and its historicity is called into doubt). The inscriptions of Ansud prove (1) that he existed in the Early Dynastic period as king of Mari, and (2) that he was roughly contemporary with Mesannipadda (showing that the "dynasties" which appear in the Sumerian king list as successive were often contemporarya situation analogous to the judges of the Bible for whom contemporaneity is not stated but likely in several cases).

The latest palace, which lay closest to the surface and which thus was excavated first, was that of the Old Babylonian period (early second millennium). It received its greatest expansion in the time of its last king, Zimri-Lim, when it covered eight acres and comprised 300 rooms, complete with throne rooms, audience chambers, schools, bakeries, wine cellars, archives, bath-rooms, and lavatories ("inside plumbing" in 1800 B.c.!). This is the palace treated by Parrot in MAM 2, noted above. It was also in this palace that most of the 20,000 tablets were found, particularly in rooms $5,110,111$, and 115 . Room 115 was re-excavated in 1972 and another hundred tablets were found, as reported by M. Birot, "Nouvelles découvertes épigraphiques au palais de Mari (Salle 115)," Syria 50 (1973): 1-11.

\section{The Texts}

Of the more than 20,000 texts excavated to date, only about one fourth have been published officially, in the series Archives royales de Mari. About two-fifths of the published texts are letters. 
The rest are economic, administrative, and juridical texts. (The main collections are noted at the end of this article.) Besides these official final publications, however, many documents have been published in preliminary form in the journals Syria, $R A$, and elsewhere.

It should be noted also that English translations of Mari texts may occasionally be found in the English-language articles cited in this report. The standard collection of ancient Near Eastern texts in English translation contains relatively few texts from Mari: ANET, 3d ed. with supplement (Princeton: Princeton University Press, 1969), pp. 482-483, 556-557, 623-625, 628-632. A few more are available in A. L. Oppenheim, Letters from Mesopotamia (Chicago: University of Chicago Press, 1967), pp. 96-110.

Virtually all of the texts of the Old Babylonian period are in Akkadian. It is clear, however, that the native language of the population was an early form of Northwest Semitic (i.e., there was a standard, official language used for business correspondence and probably utilized by the higher class of society for speech also, and there was the native, popular language spoken by the lower classes). This Northwest Semitic shows up in proper names (e.g., native Yabni-Addu as versus Akkadian Ibni-Addu) and in a few words used in a non-Akkadian sense or which are not Akkadian at all.

The texts are written on rectangular or square tablets, fatter in the middle than at the sides, made of unbaked clay. Because the tablets were originally not baked hard, they tend to be in very fragile condition when unearthed. The excavators have developed techniques for baking and cleaning the tablets shortly after discovery in order to prevent further decay.

\section{History}

From the standpoint of historical survey, the best is that of J.-R. Kupper in CAH, 3d ed., 2/1 (1973): 1-41. An older treatment is 
that of Franco Michelini Tocci, La Siria nelletà di Mari (Rome: Università di Roma, 1960).

As for the texts themselves, the letters provide first-hand historical information and are of more intrinsic value as historical documents than royal inscriptions because they deal with real life situations and lack the propagandistic bombast of documents intended for public consumption. The letters do have several drawbacks, however: (1) They were written to and from individuals who knew what they were writing about and who thus did not bother to provide all the details the modern eavesdropper would like to have. (2) Though there is less propagandistic exaggeration and deviation from the truth than in the later Assyrian royal inscriptions, we are nonetheless never sure when someone writing to the king, for example, was embroidering on the truth. (3) Not enough letters have come down through the nearly 3000 years since they were written to fill all the gaps in our information, and those which have come down are often partly broken, leaving exasperating lacunae.

The economic, administrative, and juridical texts provide the raw material for assessing how goods and services were exchanged and the legal traditions regulating such exchanges, as well as giving information on other aspects of social intercourse. An example of how these texts can be used for reconstructing political history is provided below, in the next section.

The Mari texts, coupled with information from other Mesopotamian sources, reveal the following outline of the political history of Mari in the early second millennium: (1) A local dynasty wherein the royal names Yaggid-Lim and Yahdun-Lim occur (before about 1815, according to the so-called "Middle Chronology"1); (2) foreign rule in Mari, with the king of Assyria, Shamshi-Adad, taking control of the Mari region and putting his

${ }^{1}$ For the various chronologies which have been suggested, see the discussion and bibliographies of Edward F. Campbell in The Bible and the Ancient Near East: Essays in Honor of William Foxwell Albright, ed. G. Ernest Wright (Garden City, N.Y.: Doubleday, 1961), pp. 214-224. 
son Yasmah-Adad on the throne of Mari itself (until about 1780); and (3) the local dynasty regaining ascendancy, with Zimri-Lim, son of Yahdun-Lim, retaking the throne of Mari. In this lastmentioned enterprise, Zimri-Lim was aided by his father-in-law, Yarim-Lim (notice the -Lim name), king of the Syrian kingdom of Yamhad. Finally, Mari was destroyed by the famous Hammurapi of Babylon in the latter's 35th regnal year (about 1757).

Beyond this bare skeleton of historical information, there is a vast amount of information in these letters about the administration of Mari and its dependent towns, and about Mari's relationships with other towns and nations of the time.

\section{History of Neighboring Areas}

The Mari texts are extremely useful in establishing the history and geography of northern Mesopotamia, but for the student of Syro-Palestinian history the references to the western countries are of paramount interest. We have already seen that Zimri-Lim was married to the daughter of Yarim-Lim, king of Yambad in Syria. His predecessor, Yasmah-Adad of the Assyrian regency, was also married to a Syrian princess, the daughter of Ishhi-Adad, king of Qatna, another town located in central Syria (which would indicate a rivalry between two of the major political centers in Syria).

The kind of information we can expect from the Mari texts is well illustrated by an economic document, recently published by G. Dossin, "La route de l'étain en Mésopotamie au temps de Zimri-Lim," RA 64 (1970): 97-106 (quoted here from A. Malamat, "Syro-Palestinian Destinations in a Mari Tin Inventory," IEJ 21 [1971]: 34):

10 minas tin (for) Sumu-Erah

at Muzunnum;

$81 / 3$ minas tin (for) Wari-taldu

at Laish;

30 minas tin (for) Ibni-Adad, king of Hazor.

Comptroller: Add[ . . . ] at Hazazar,

for the first time; 
20 minas tin (for) Amud-pi-El,

20 minas tin (for) Ibni-Adad,

[for the] second time;

$[x]$ minas tin for the Caphtorite,

I [ + ? minas] tin for the dragoman,

[x minas tin for] the Carian (?),

[at Ug]arit;

20 (?) [minas tin for Ib]ni-Adad for the third time;

This short document mentions shipments of tin to two wellknown places in Palestine (Hazor, located about ten miles north of the Sea of Galilee, and Laish, the ancient name of Dan, located at the northern extremity of Israel near Mt. Hermon); two less well-known places (Muzunnum and Hazazar ${ }^{2}$ ); Amudpi-El, then king of Qatna; the city of Ugarit, on the far northern coast of Phoenicia; and a Caphtorite (Cretan). Malamat, in IEJ 21 (1971): 35, has called the reference to Wari-Taldu, king of Laish "the plum for the Palestinologist." It is indeed of extreme interest to find the king of Laish in northern Palestine bearing a name which must be identified as Hurrian, especially at so early a period. ${ }^{3}$ References to the cities of Palestine are so rare that a mention of Laish providing the ruler's name is indeed a real "plum."

\section{Social History}

These texts also provide material for research for many years to come into the social aspects of the early West Semitic peoples who lived in and around Mari. Some aspects of this social history have already been treated, but much remains to be done, especially as more texts are published. Some of the areas that have been studied thus far are as follows:

Nomadism: J.-R. Kupper, Les nomades en Mésopotamie au temps des rois de Mari (Paris: Belles Lettres, 1957);

\footnotetext{
${ }^{2}$ For the localization of these two places, see M. C. Astour in $R A 67$ (1973): 73-75.

${ }^{3}$ For the Hurrians at the beginning of the second millennium, see Kupper's chapter in $C A H$ mentioned above.
} 
Military Structures: Jack M. Sasson, The Military Establishments at Mari (Rome: Pontifical Biblical Institute, 1969);

Tribal Organization: A. Malamat, "Mari and the Bible: Some Patterns of Tribal Organization and Institutions," JAOS 82 (1962): 143-150;

The Position of Women: H. F. Batto, Studies on Women at Mari (Baltimore and London: The Johns Hopkins University Press, 1974) .

\section{Linguistic History}

Though the Mari texts are consistently written in good Akkadian, there is enough information from proper names and nonAkkadian words to outline the linguistic structure of the language spoken by the West Semites of the Mari region. I. J. Gelb, of the University of Chicago, has published a short grammar of this language (commonly, but properly only as a convention, referred to as "Amorite" ) : "La lingua degli Amoriti," Atti della Academia Nazionale dei Lincei, Rendiconti: Classe di Scienze morali, storiche e filologiche, ser. 8, vol. 13 (1958): 143-164. He is presently working on a further grammar of the language as derived by means of the computer.

A. Malamat has frequently referred to the non-Akkadian words or meanings found in the Mari texts. See his JAOS article mentioned in the preceding section on "Social History" and also "Mari" in BA 34 (1971): 1-22. Some examples of such nonAkkadian words or meanings are gāyum (a term for a tribal subgroup), related to Hebrew gôy "nation"; ummatum (another tribal term), related to Hebrew 'ummâa, also meaning "nation" (and rarely, as at Mari, a tribal unit; cf. Gen 25:16 and Num 25:15); hamqum - Hebrew 'èmeq, "valley"; and higlum = Hebrew 'ègel, "calf."

"The term "Amorite," derived from the Akkadian word for the West, amurru, was often used to refer to those West Semites who were entering Mesopotamia from the West. The term is somewhat incorrect, however, in that (1) it probably was originally a place name or tribal name of very limited applicability and not a generic term for West Semites as a whole, and (2) it was never used by the West Semites of Mari to describe themselves (the word appears only rarely there as a designation of a small tribal subdivision). 


\section{Religious History}

Both non-literary sources (such as altars of earth illustrated by Malamat in BA 34 [1971]: 14, fig. 6) and literary sources provide information of great interest for the religious history of the early West Semites. The appearance of deities well known from later Syro-Palestinian sources, for instance, shows that these deities had a long background (such deities as Dagan, god of grain, and Haddu/Hadad/Addu/Adad, storm-god, etc.).

Of greatest interest, however, is the series of texts containing references to prophetism among the inhabitants of Mari and neighboring towns (as far south as Sippar in Babylonia). To date, twenty-seven Mari letters have been discovered which contain references to communications from persons claiming to have dreams or direct messages from deities. These messages are directed from the deity to a third party, usually the king. Before the appearance of the Mari texts, induced divine guidance by various divination practices (extispicy, interpretation of smoke patterns, of oil patterns on water, of the flight of birds, etc.) was well known from Mesopotamian sources. ${ }^{5}$ The "message-dream" was also known, though it was not common. ${ }^{6}$ The modality of the Mari dream messages, however, and the phenomenon of immediately perceived prophetic messages are for all practical purposes unparalleled outside of the OT. ${ }^{7}$

As would be expected, this new source of material for comparison with the OT has elicited a flood of response. One major book has already been devoted to the subject: Friedrich Ellermeier, Prophetie in Mari und Israel (Herzberg: Erwin Jungfer, 1968).

${ }^{5}$ For the distinction between divination and prophecy, see Herbert Huffmon, "Prophecy in the Mari Letters," $B A 31$ (1968):101-124, esp. pp. 102-103.

${ }^{B}$ A. L. Oppenheim, The Interpretation of Dreams in the Ancient Near East, Transactions of the American Philosophical Society, n. s., 46/3 (1956): 193-206.

"James F. Ross has recently discussed the previously best known extrabiblical reference to "seers" from West Semitic sources: "Prophecy in Hamath, Israel, and Mari," HTR 63 (1970):1-28. For the more literary prophecies from Mesopotamian sources, see H. Hunger and S. A. Kaufman, "A New Akkadian Prophecy Text," JAOS 95 (1975):371-375. 
(For a convenient summary of this work, see the review by S. D. Walters, JBL 89 [1970]: 78-81.) The most recent and, in many respects, the handiest coverage of the subject is by John F. Graghan, "Mari and its Prophets: The Contributions of Mari to the Understanding of Biblical Prophecy," Biblical Theology Bulletin 5 (1975) : 32-55. This article contains the bibliographical references necessary to trace previous discussions of the material as well as providing an overview of the main lines which these discussions have followed. The most extensive recent attempt to place Mari prophecy in the context of general ancient Near Eastern prophecy is by Herbert B. Huffmon, "The Origins of Prophecy," in Magnalia Dei: The Mighty Acts of God. Essays on the Bible and Archaeology in Memory of G. Ernest Wright, ed. Frank Moore Cross, et al. (Garden City, N.Y.: Doubleday, 1976), pp. 171-186. Many of the Mari prophecy texts are available in English translation in ANET.

As an example of the Mari prophetic texts, I cite one which has so far been published only in French translation, by G. Dossin, "Sur le prophétisme à Mari," in La divination en Mésopotamie ancienne (Paris: Presses Universitaires de France, 1966), pp. 85-86. It is unique in that it is the only letter to date which was written by a prophet himself, all the others having been conveyed by an intermediary. It is not complete, but the sections provided by the editor are as follows:

Speak thus to Zimri-Lim: thus (says) the āpilum-prophet [literally "the answerer (of questions)"] of Shamash [the sun-god]. Thus says Shamash, lord of the country: "Please send immediately to me in Sippar, in order that prosperity continue [literally "for life"], the throne intended for my splendid residence, as well as your daughter whom I already have requested of you. .. . Now, as concerns Hammurapi, king of Kurda, he has spoken criminally against you. But when he attacks, you will be victorious; thereafter you are to relieve the land of its indebtedness. I grant you the whole land. When you take the city, you are to declare amnesty from debts.

This text reveals two of the main concerns of the Mari prophetic messages: (1) proper care of the deities, their temples, and the 
temple-services; and (2) promises of military success (or threats of defeat in other cases).

The main concern of most researchers with a background in OT studies has been that of comparing the Mari materials with the OT prophets. This research has dealt with matters of form, factual content, and sociological considerations; i.e., do the Mari prophets use the same type of language as the biblical prophets, do they talk about the same things, and do they fill the same role in society? The answers to all three questions are Yes and No.

OT form-critics immediately picked out the formula " $x$-deity has sent me," so similar to many such statements in the Bible. The main thrust of Ellermeier's book, however, has been to show that there are too many variations in formulae at Mari to say that the "messenger-formula" was primary. The content of the letters shows many points of comparison with the OT (a repeated announcement to Zimri-Lim that he would be victorious over Babylon is reminiscent of biblical oracles of the same type; unfortunately, the Mari prediction was incorrect since Hammurapi of Babylon eventually destroyed Mari [compare $2 \mathrm{Chr}$ 18]). One immediately misses, however, the strong moral emphasis of the Bible prophets. In this respect, the letter cited above is typical of the preoccupations of the Mari prophets. As for the role played by these prophets, it seems to be quite comparable to that of the Israelite prophets under unresponsive kings. ${ }^{8}$ Jeremiah, e.g., was heard, but only occasionally heeded, and had no real impact on the political events of his time because of the lack of attention paid to him.

The very large place that some of the Israelite prophets assume in our thinking today is mainly due to the fact that their literary creations, often of very high quality, have come down to us. We must be careful in comparing the role of the Mari prophets

${ }^{8} \mathrm{~J}$. S. Holladay has recently charted the development of Israelite prophets from court prophets (as at Mari) to populist prophets (i.e., their message was directed to the people rather than primarily to the king): "Assyrian Statecraft and the Prophets of Israel," HTR 63 (1970):29-51. 
with that of the OT prophets for two reasons: (1) We have very little evidence with regard to the response accorded the messages of the Mari prophets (one Mari prophet, it may be noted, did claim that the present message was the sixth he had given on the matter in question; this apparently indicates a general slowness to comply on the part of Mari royalty); and (2) we have no literary production from the Mari prophets which is in any way comparable to that of the Israelite prophets. We can, in any case, say that the choice by the God of Israel of prophets as intermediaries between himself and his people was not a new and unfamiliar mode of communication. As with many aspects of Israelite religion, prophetism was an old phenomenon, raised to new heights of moral and aesthetic quality. ${ }^{9}$

\section{Mari and the Bible}

Much has, of course, been written in the last forty years about the importance of Mari for the Bible. We have already seen how valuable the Mari texts are for reconstructing the political history of Palestine and Syria in the early second millennium B.C., for establishing the prehistory of the West Semitic languages, and for tracing an early form of prophetism.

We enter upon a different level of use of these texts, however, with certain interpretations of biblical chronology wherein the patriarchs of Genesis are dated to the same general period as the Mari documents. There is little, unfortunately, beyond comparison of proper names (of persons and places) to link these texts with the patriarchs. Closer and more numerous links of a social nature, such as marriage and family customs, are discernible, in fact, with the texts from another and later site-fifteenthcentury Nuzi.

${ }^{9}$ It may be noted that A. Marzal has studied the main forms of law as analyzed by form critics of the OT ("apodictic" and "casuistic"). He concludes that "both formulations are attested in Mari at the same time; the subject matter and the setting in life are not the factors which finally determine the selection of one formulation over another" (CBQ 33 [1971]: 509). Here, then, is another area of form criticism for which the Mari material seems to provide negative rather than positive evidence. 
A recent book by Thomas L. Thompson, The Historicity of the Patriarchal Narratives: The Quest for the Historical Abraham, Beiheft zur Zeitschrift für die alttestamentliche Wissenschaft, 133 (Berlin: de Gruyter, 1974), has shown that the proper names and social customs from both Mari and Nuzi which have been compared with the patriarchal narratives find parallels from periods ranging from 2000 to 500 B.C. Thompson has also claimed that without a specific link between the patriarchal narratives and extrabiblical texts, we have no sure way of dating the patriarchs (or even, according to him, of asserting their existence). The argument is based on silence (no monument, e.g., has yet mentioned Abraham by name) and is, in a sense, unfair (the statistical chances of finding a contemporaneous reference to Abraham are practically nil).

One must, nonetheless, give heed to Thompson's argument: A secular historian dealing with the history of Syria-Palestine in the early second millennium could not assert that the patriarchs were historical personages, simply because the Bible is the only document that refers to them (one of the dicta of historical research is testis unus testis nullus, "one witness only is no witness at all"). One could, however, even as a secular historian, assert that the patriarchs may well have been historical personages because so much of the rest of the Bible has been proved true by the historical and archaeological research of the last century. This is essentially the approach of the so-called "Albright school" of historians (who follow the methodology of the late W. F. Albright, for many years the dean of American biblical archaeologists), typified by John Bright in his A History of Israel (Philadelphia: Westminster, 1959, 1972).

Other historians, such as Thompson and also John van Seters, Abraham in History and Tradition (New Haven: Yale University Press, 1975), remain much more skeptical about projecting the historicity of those sections of the Bible which report the royal and exilic periods back into the patriarchal period. From a strictly 
evidential point of view, we must await further discoveries to elucidate the early second millennium B.c. It appears that the discoveries at Tell Mardikh west of Mari in Syria, just now beginning to be reported in detail, will provide further evidence for personal and geographic names mentioned in the patriarchal narratives as well as for a language much like Biblical Hebrew. These discoveries have brought to light materials from ca. 2500 B.C., several hundred years before the main Mari archives and the traditional dating of the patriarchs. Mari has taught us much, but we have every reason to believe that the soil of the Fertile Crescent has much to teach us yet.

\section{NOTE REGARDING THE PUBLICATION OF THE MARI TEXTS}

The official publications of the Mari texts (see p. 191, above) are appearing in two parallel series, the first containing only hand copies of the tablets themselves (in the series Textes cuneiformes du Louvre, since 1976 in the new series Textes cunéiformes de Mari, available through Geuthner in Paris), the second containing transliterations of the Akkadian signs into roman characters and a French translation, usually with some form of commentary and/ or glossary. Unfortunately, the publication dates of corresponding volumes varies, so a given volume may have appeared only in hand copies or only in transliteration. Moreover, both series go by the same name: Archives royales de Mari. As a convention, the hand copies are usually abbreviated $A R M$ and the accompanying volume of transliterations and translations $A R M T$. Following is a list of the titles:

ARM 1 (TCL 22, 1946, republished 1967), G. Dossin, Correspondance de Šamši-Addu et de ses fils (= ARMT 1, Imprimerie nationale, 1950).

ARM 2 (TCL 23, 1942, republished 1973), Charles-F. Jean, Lettres diverses (= ARMT 2, Imprimerie nationale, 1950).

ARM 3 (TCL 24, 1948), J. R. Kupper, Correspondance de Kibri-Dagan gouverneur de Terqa (= ARMT 3, Imprimerie nationale, 1950).

ARM 4 (TCL 25, 1951), G. Dossin, Correspondance de Šamši-Addu (=ARMT 4, Imprimerie nationale, 1951).

ARM 5 (TCL 26, 1951), G. Dossin, Correspondence de Iasmah-Addu (=ARMT 5, Imprimerie nationale, 1952).

ARM 6 (TCL 27, 1953), J. R. Kupper, Correspondance de Bahdi-Lim préfet du palais de Mari (=ARMT 6, Imprimerie nationale, 1954).

ARM 7 (TCL 28, 1956), Jean Bottéro, Textes économiques et administratives de la salle 110 (= ARMT 7, Imprimerie nationale, 1957).

ARM 8 (TCL 29, 1957), Georges Boyer, Textes juridiques (=ARMT 8, Imprimerie nationale, 1958). 
ARM 9 (TCL 30, 1960), Maurice Birot, Textes administratifs de la salle 5 $d u$ palais (=ARMT 9, Imprimerie nationale, 1960).

ARM 10 (TCL 31, 1967), G. Dossin, La correspondance féminine (ARMT 10 has not yet appeared).

ARMT 11 (Geuthner, 1963), Madeleine Lurton Burke, Textes administratifs de la salle 111 du palais (ARM 11 unpublished).

ARMT 12 (Geuthner, 1964), M. Birot, Textes administratifs de la salle 5 du palais (2ème partie) (ARM 12 unpublished).

ARMT 13 (Geuthner, 1964), G. Dossin, J. Bottéro, M. Birot, M. L. Burke, J.-R. Kupper, A. Finet, Textes Divers (ARM 13 unpublished).

ARM 14 (TCM 1, 1976), Maurice Birot, Lettres de Yaqqim-Addu, gouverneur de Sagarâtum (=ARMT 14, Geuthner, 1974).

ARMT 15 (Imprimerie nationale, 1954), J. Bottéro, A. Finet, Répertoire analytique des tomes $I$ à $V$ (sign list, glossary, etc., for volumes 1-5; contains no new texts so there is no corresponding $A R M$ volume).

ARM 18 (TCM 2, 1976), O. Rouault, Mukannisum: lettres et documents administratifs (ARMT 18 has not yet appeared).

ARM 19 (TCM 3, 1976), Henri Limet, Textes administratifs de l'époque des šakkanakku (=ARMT 19, Geuthner, 1976).

ARM 20 (TCM 4, announced), G. Dossin, Correspondance d'Itûr-Addu. 